\title{
(6) \\ Why ban the sale of cigarettes? The case for abolition
} OPEN ACCESS

\author{
Robert N Proctor
}

\section{Correspondence to \\ Dr Robert N Proctor, Department of History, Stanford University, Bldg 200, Stanford, CA 94305, USA; rproctor@stanford.edu}

Received 25 October 2012 Revised 16 January 2013 Accepted 17 January 2013
To cite: Proctor RN. Tob

Control 2013;22:i27-i30.

\begin{abstract}
The cigarette is the deadliest artefact in the history of human civilisation. Most of the richer countries of the globe, however, are making progress in reducing both smoking rates and overall consumption. Many different methods have been proposed to steepen this downward slope, including increased taxation, bans on advertising, promotion of cessation, and expansion of smoke-free spaces. One option that deserves more attention is the enactment of local or national bans on the sale of cigarettes. There are precedents: 15 US states enacted bans on the sale of cigarettes from 1890 to 1927, for instance, and such laws are still fully within the power of local communities and state governments. Apart from reducing human suffering, abolishing the sale of cigarettes would result in savings in the realm of healthcare costs, increased labour productivity, lessened harms from fires, reduced consumption of scarce physical resources, and a smaller global carbon footprint. Abolition would also put a halt to one of the principal sources of corruption in modern civilisation, and would effectively eliminate one of the historical forces behind global warming denial and environmental obfuscation. The primary reason for abolition, however, is that smokers themselves dislike the fact they smoke. Smoking is not a recreational drug, and abolishing cigarettes would therefore enlarge rather than restrict human liberties. Abolition would also help cigarette makers fulfil their repeated promises to 'cease production' if cigarettes were ever found to be causing harm.
\end{abstract}

\section{SIX REASONS TO BAN}

The cigarette is the deadliest object in the history of human civilisation. Cigarettes kill about 6 million people every year, a number that will grow before it shrinks. Smoking in the twentieth century killed only 100 million people, whereas a billion could perish in our century unless we reverse course. ${ }^{1}$ Even if present rates of consumption drop steadily to zero by 2100 , we will still have about 300 million tobacco deaths this century.

The cigarette is also a defective product, meaning not just dangerous but unreasonably dangerous, killing half its long-term users. And addictive by design. It is fully within the power of the Food and Drug Administration in the US, for instance, to require that the nicotine in cigarettes be reduced to subcompensable, subaddictive levels. ${ }^{2}{ }^{3}$ This is not hard from a manufacturing point of view: the nicotine alkaloid is water soluble, and denicotinised cigarettes were already being made in the 19 th century. ${ }^{4}$ Philip Morris in the 1980s set up an entire factory to make its Next brand cigarettes, using supercritical fluid extraction techniques to achieve a $97 \%$ reduction in nicotine content, which is what would be required for a $0.1 \%$ nicotine cigarette, down from present values of about $2 \% .^{5}$ Keep in mind that we're talking about nicotine content in the rod as opposed to deliveries measured by the 'FTC method', which cannot capture how people actually smoke. ${ }^{5}$

Cigarettes are also defective because they have been engineered to produce an inhalable smoke. Tobacco smoke was rarely inhaled prior to the nineteenth century; it was too harsh, too alkaline. Smoke first became inhalable with the invention of flue curing, a technique by which the tobacco leaf is heated during fermentation, preserving the sugars naturally present in the unprocessed leaf. Sugars when they burn produce acids, which lower the $\mathrm{pH}$ of the resulting smoke, making it less harsh, more inhalable. There is a certain irony here, since these 'milder' cigarettes were actually far more deadly, allowing smoke to be drawn deep into the lungs. The world's present epidemic of lung cancer is almost entirely due to the use of low $\mathrm{pH}$ flue-cured tobacco in cigarettes, an industry-wide practice that could be reversed at any time. Regulatory agencies should mandate a significant reduction in rodcontent nicotine, but they should also require that no cigarette be sold with a smoke $\mathrm{pH}$ lower than 8. Those two mandates alone would do more for public health than any previous law in history. ${ }^{5}$

Death and product defect are two reasons to abolish the sale of cigarettes, but there are others. A third is the financial burden on public and private treasuries, principally from the costs of treating illnesses due to smoking. Cigarette use also results in financial losses from diminished labor productivity, and in many parts of the world makes the poor even poorer. ${ }^{6}$

A fourth reason is that the cigarette industry is a powerful corrupting force in human civilisation. Big tobacco has corrupted science by sponsoring 'decoy' or 'distraction research', ${ }^{5}$ but it has also corrupted popular media, insofar as newspapers and magazines dependent on tobacco advertising for revenues have been reluctant to publish critiques of cigarettes. ${ }^{7}$ The industry has corrupted even the information environment of its own workforce, as when Philip Morris paid its insurance provider (CIGNA) to censor the health information sent to corporate employees. ${ }^{8}$ Tobacco companies have bullied, corrupted or exploited countless other institutions: the American Medical Association, the American Law Institute, sports organisations, fire-fighting bodies, Hollywood, the 
US Congress-even the US presidency and US military. President Lyndon Johnson refused to endorse the 1964 Surgeon General's report, for instance, fearing alienation of the tobaccofriendly South. Cigarette makers managed even to thwart the US Navy's efforts to go smoke-free. In 1986, the Navy had announced a goal of creating a smoke-free Navy by the year 2000; tobacco-friendly congressmen were pressured to thwart that plan, and a law was passed requiring that all ships sell cigarettes and allow smoking. The result: American submarines were not smoke-free until $2011 .^{9}$

Cigarettes are also, though, a significant cause of harm to the natural environment. Cigarette manufacturing consumes scarce resources in growing, curing, rolling, flavouring, packaging, transport, advertising and legal defence, but also causes harms from massive pesticide use and deforestation. Many Manhattans of savannah woodlands are lost every year to obtain the charcoal used for flue curing. Cigarette manufacturing also produces non-trivial greenhouse gas emissions, principally from the fossil fuels used for curing and transport, fires from careless disposal of butts, and increased medical costs from maladies caused by smoking ${ }^{5}$ (China produces 40 percent of the world's cigarettes, for example, and uses mainly coal to cure its tobacco leaf). And cigarette makers have provided substantial funding and institutional support for global climate change deniers, causing further harm. ${ }^{10}$ Cigarettes are not sustainable in a world of global warming; indeed they are one of its overlooked and easily preventable causes.

But the sixth and most important reason for abolition is the fact that smokers themselves do not like their habit. This is a key point: smoking is not a recreational drug; most smokers do not like the fact they smoke and wish they could quit. This means that cigarettes are very different from alcohol or even marijuana. Only about $10-15 \%$ of people who drink liquor ever become alcoholics, versus addiction rates of $80 \%$ or $90 \%$ for people who smoke. ${ }^{11}$ As an influential Canadian tobacco executive once confessed: smoking is not like drinking, it is rather like being an alcoholic. ${ }^{12}$

\section{THE SPECTRE OF PROHIBITION}

An objection commonly raised is: Hasn't prohibition already been tried and failed? Won't this just encourage smuggling, organised crime, and yet another failed war on drugs? That has been the argument of the industry for decades; bans are ridiculed as impractical or tyrannical. (First they come for your cigarettes.... $)^{13}$

The freedom objection is weak, however, given how people actually experience addiction. Most smokers 'enjoy' smoking only in the sense that it relieves the pains of withdrawal; they need nicotine to feel normal. People who say they enjoy cigarettes are rather rare-so rare that the industry used to call them 'enjoyers' ${ }^{14}$ Surveys show that most smokers want to quit but cannot; they also regret having started. ${ }^{15}$ Tobacco industry executives have long grasped the point: Imperial Tobacco's Robert Bexon in 1984 confided to his Canadian cotobacconists that 'If our product was not addictive we would not sell a cigarette next week'. ${ }^{12}$ American cigarette makers have been quietly celebrating addiction since the 1950s, when one expressed how 'fortunate for us' it was that cigarettes 'are a habit they can't break'. 16

Another objection commonly raised to any call for a ban is that this will encourage smuggling, or even organised crime. But that is rather like blaming theft on fat wallets. Smuggling is already rampant in the cigarette world, as a result of pricing disparities and the tolerance of contraband or even its encouragement by cigarette manufacturers. Luk Joossens and Rob Cunningham have shown how cigarette manufacturers have used smuggling to undermine monopolies or gain entry into new markets or evade taxation. ${ }^{17} 18$ And demand for contraband should diminish, once the addicted overcome their addiction-a situation very different from prohibition of alcohol, where drinking was a more recreational drug. And of course, even a ban on the sale of cigarettes will not eliminate all smoking-nor should that be our goal, since people should still be free to grow their own for personal use. Possession should not be criminalised; the goal should only be a ban on sales. Enforcement, therefore, should be a trivial matter, as is proper in a liberal society.

Cigarette smoking itself, though, is less an expression of freedom than the robbery of it. And so long as we allow the companies to cast themselves as defenders of liberty, the table is unfairly tilted. We have to recognise that smoking compromises freedom, and that retiring cigarettes would enlarge human liberties.

Of course it could well be that product regulation, combined with taxation, denormalisation, and 'smoke-free' legislation, will be enough to dramatically lower or even eliminate cigarette use-over some period of decades. Here, though, I think we fail to realise how much power governments already have to act more decisively. From 1890 to 1927 the sale of cigarettes was banned virtually overnight in 15 different US states; and in Austin v. Tennessee (1900) the US Supreme Court upheld the right of states to enact such bans. ${ }^{19}$ Those laws all eventually disappeared from industry pressure and the lure of tax revenues. ${ }^{20}$ None was deemed unconstitutional, however, and some localities retained bans into the 1930 s, just as some counties still today ban the sale of alcohol. Bhutan in 2004 became the first nation recently to ban the sale of cigarettes, and we may see other countries taking this step, especially once smoking prevalence rates start dropping into single digits.

\section{HELPING THE INDUSTRY FULFIL ITS PROMISES}

One last rationale for a ban: abolition would fulfil a promise made repeatedly by the industry itself. Time and again, cigarette makers have insisted that if cigarettes were ever found to be causing harm they would stop making them:

- In March 1954, George Weissman, head of marketing at Philip Morris, announced that his company would 'stop business tomorrow' if 'we had any thought or knowledge that in any way we were selling a product harmful to consumers'. 21

- In 1972, James C Bowling, vice president for public relations at Philip Morris, asserted publicly, and in no uncertain terms, that 'If our product is harmful...we'll stop making it'. 22

- Helmut Wakeham, vice president for research at Philip Morris, in 1976 stated publicly that if the company as a whole believed that cigarettes were really harmful, we would not be in the business. We are a very moralistic company'. 23

- RJ Reynolds president Gerald H Long, in a 1986 interview asserted that if he ever 'saw or thought there were any evidence whatsoever that conclusively proved that, in some way, tobacco was harmful to people, and I believed it in my heart and my soul, then I would get out of the business. 24 
- Philip Morris CEO Geoffrey Bible in 1997, when asked (under oath) what he would do with his company if cigarettes were ever found to be causing cancer, said: 'I'd probably...shut it down instantly to get a better hold on things'. ${ }^{25}$ Bible was asked about this in Minnesota $v$. Philip Morris (2 March 1998) and reaffirmed that if even one person were ever found to have died from smoking he would 'reassess' his duties as CEO. ${ }^{26}$

The clearest expression of such an opinion, however, was by Lorillard's president, Curtis H Judge, in an April 1984 deposition, where he was asked why he regarded Lorillard's position on smoking and health as important:

A: Because if we are marketing a product that we know causes cancer, I'd get out of the business...I wouldn't be associated with marketing a product like that.

Q: Why?

A: If cigarettes caused cancer, I wouldn't be involved with them...I wouldn't sell a product that caused cancer.

Q: ...Because you don't want to kill people? ... Is that the reason?

A: Yes.

Q: ...If it was proven to you that cigarette smoking caused lung cancer, do you think cigarettes should be marketed?

A: No...No one should sell a product that is a proven cause of lung cancer. ${ }^{27}$

Note that these are all public assurances, including several made under oath. All follow a script drawn up by the industry's public relations advisors during the earliest stages of the conspiracy: On 14 December 1953, Hill and Knowlton had proposed to RJ Reynolds that the cigarette maker reassure the public that it 'would never market a product which is in any way harmful'. Reynolds was also advised to make it clear that

If the Company felt that its product were now causing cancer or any other disease, it would immediately cease production of it. ${ }^{28}$

To this recommendation was added 'Until such time as these charges or irresponsible statements are ever proven, the Company will continue to produce and market cigarettes'.

What is remarkable is that we never find the companies saying privately that they would stop making cigarettes-with two significant exceptions. In August 1947, in an internal document outlining plans to study 'vascular and cardiac effects' of smoking, Philip Morris's director of research, Willard Greenwald, made precisely this claim: 'We certainly do not want any person to smoke if it is dangerous to his health'. ${ }^{29}$ Greenwald had made a similar statement in 1939 , reassuring his president, $\mathrm{OH}$ Chalkley, that 'under no circumstances would we want anyone to smoke Philip Morris cigarettes were smoking definitely deleterious to his health'. ${ }^{30}$ There is no reason to believe he was lying: he is writing long before Wynder's mouse painting experiments of 1953, and prior even to the epidemiology of 1950. Prior to obtaining proof of harm, Philip Morris seems honestly not to have wanted to sell a deadly product.

Abolition is not such a radical idea; it would really just help the industry fulfil its long-standing promises to the public. The cigarette, as presently constituted, is simply too dangerous-and destructive and unloved-to be sold.

\section{Summary points}

- The cigarette is the deadliest object in the history of human civilisation. It is also a defective product, a financial burden on cash-strapped societies, an important source of political and scientific corruption, and a cause of both global warming and global warming denial.

- Tobacco manufacturers have a long history of promising to stop the production of cigarettes, should they ever be proven harmful.

- The most important reason to ban the sale of cigarettes, however, is that most smokers do not even like the fact they smoke; cigarettes are not a recreational drug.

- It is not in principle difficult to end the sale of cigarettes; most communities-even small towns-could do this virtually overnight. We actually have more power than we realize to put an end this, the world's leading cause of death and disease.

Competing interests The author has served as an expert witness for plaintiffs in tobacco litigation.

Provenance and peer review Not commissioned; externally peer reviewed.

Open Access This is an Open Access article distributed in accordance with the Creative Commons Attribution Non Commercial (CC BY-NC 3.0) license, which permits others to distribute, remix, adapt, build upon this work non-commercially, and license their derivative works on different terms, provided the original work is properly cited and the use is non-commercial. See: http://creativecommons.org/ licenses/by-nc/3.0/

\section{REFERENCES}

1 Proctor RN. Tobacco and the global lung cancer epidemic. Nat Rev Cancer 2001;1:82-7

2 Benowitz NL, Henningfield J. Establishing a nicotine threshold for addiction. N Eng/ J Med 1994;331:123-25.

3 Hatsukami DK, Perkins KA, LeSage MG, et al. Nicotine reduction revisited: science and future directions. Tob Control 2010;19:e1-10.

4 Wenusch A. Der tabakrauch. Seine entstehung, beschaffenheit und zusammensetzung. Bremen: Arthur Geist, 1939.

5 Proctor RN. Golden holocaust: origins of the cigarette catastrophe and the case for abolition. Berkeley: University of California Press, 2011.

6 Peretti-Watel P, Seror V, Constance J, et al. Poverty as a smoking trap. Int J Drug Policy 2009;20:230-6.

7 Guyon J. Do publications avoid anti-cigarette stories to protect ad dollars? Wall Street J 1982:1.

8 Muggli ME, Hurt RD. A cigarette manufacturer and a managed care company collaborate to censor health information targeted at employees. Am J Public Health 2004;94:1307-11.

9 Offen N, Arvey S, Smith EA, et al. Forcing the Navy to sell cigarettes on ships: how the tobacco industry and politicians torpedoed Navy tobacco control. Am J Public Health 2011;101:404-11.

10 Oreskes N, Conway EM. Merchants of doubt: how a handful of scientists obscured the truth on issues from tobacco smoke to global warming. New York: Bloomsbury, 2010.

11 Giovino GA, Henningfield JE, Tomar SL, et al. Epidemiology of tobacco use and dependence. Epidemiol Rev 1995;17:48-65.

12 Bexon RL. To ITL President Wilmat Tennyson and W. Sanders, File Viking, 1985, CTRL No. 3784, p. 2.

13 Lender ME. A new prohibition? An essay on drinking and smoking in America. Louisville: Brown \& Williamson, 1995.

14 A Study of Cigarette Smokers' Habits and Attitudes in 1970. May 1970. Philip Morris. http://legacy.library.ucsf.edu/tid/jyx81a00 (accessed 4 Apr 2012). pp. 13, 18,39

15 Fong G, Hammond D, Laux FL, et al. Near-universal experience of regret among smokers in four countries. Nicotine Tob Res 2004;6:S341-51.

16 Dakin EA. (Hill \& Knowlton). Forwarding Memorandum, Dec. 1953. http://legacy. library.ucsf.edu/tid/gyn66b00 (accessed 1 Jun 2012).

17 Joossens L, Raw M. Cigarette smuggling in Europe, who really benefits? Tob Control 1998:7:66-71. 
18 Cunningham R. Smoke and mirrors: the Canadian tobacco war. Ottawa: IDRC 1996.

19 Austin vs. State of Tennessee, Decided Nov. 19. Cases argued and decided in the Supreme Court, Book 45. Rochester: Lawyers Co-operative Publishing, 1900: 224-43.

20 Linder M. "Inherently bad, and bad only": a history of state-level regulation of cigarettes and smoking in the United States since the 1880s. lowa City, 2012. http://ir.uiowa.edu/cgi/viewcontent.cgi?article=1001\&context=books (accessed 1 Jun 2012).

21 Weissman G. Public relations and cigarette marketing, in St. Paul Press, March 30, 1954, Bates 1002366403-6408, http://legacy.library.ucsf.edu/tid/ovd38e00, and Bates 3039590020-0025. http://legacy.library.ucsf.edu/tid/xpv94g00 (accessed 1 Jun 2012).

22 Kwitny J. Defending the weed: how embattled group uses tact, calculation to blunt its opposition. Wall Street J 1972:1,14.

23 Wakeham H. Interviewed for Death in the West (Thames Television, 1976 ), http://www.youtube.com/watch?v=In204rPdTfQ (accessed 1 Jun 2012).

24 McKenzie R. A loyalist views tobacco's fate. Insight, May 19, 1986, p. 15, Bates 515836770. http://legacy.library.ucsf.edu/tid/pdg92d00 (accessed 1 Jun 2012)
25 Bible G. Testimony in Florida v. American Tobacco. Aug. 21, 1997, Bates 2083493341-3364, p. 27. http://legacy.library.ucsf.edu/tid/eik48c00 (accessed 1 Jun 2012).

26 Bible G. Testimony in Minnesota v. Philip Morris. March 2, 1998, Bates BIBLEG030298, pp. 5707-09. http://legacy.library.ucsf.edu/tid/gyn05a00 (accessed 1 Jun 2012).

27 Judge C. (Lorillard). Deposition testimony for Cipollone v. Liggett, 1984, pp. 251-54. http://legacy.library.ucsf.edu/tid/kms07a00 (accessed 1 Jun 2012).

28 Hill and Knowlton. Suggested approach and comments regarding attacks on use of cigarettes. 1953. Bates 3799, http://legacy.library.ucsf.edu/tid/ta066b00 (accessed 1 Jun 2012).

29 Greenwald WF. (Philip Morris). Recommendations and budget for activities of the Research Department. Aug. 1947. http://legacy.library.ucsf.edu/tid/krd38e00; http://legacy.library.ucsf.edu/tid/nhw74e00 (with thanks to Brianna Rego) (accessed 1 Jun 2012).

30 Greenwald WF. (Philip Morris). Activities of the Research Department for 1938. 1939, Bates 1003072716-2722. http://legacy.library.ucsf.edu/tid/srd38e00 (accessed 1 Jun 2012). 